RESPIRATORY INFECTION

\title{
High incidence of pulmonary bacterial co-infection in children with severe respiratory syncytial virus (RSV) bronchiolitis
}

\author{
K Thorburn, S Harigopal, V Reddy, N Taylor, H K F van Saene
}

See end of article for authors' affiliations

Correspondence to Dr K Thorburn, Department of 'Paediatric Intensive Care, Royal Liverpool Children's Hospital, Liverpool L12 2AP, UK; kent.thorburn@ rlc.nhs.uk

Received 21 June 2005 Accepted 9 March 2006 Published Online First 14 March 2006
Background: Respiratory syncytial virus (RSV) is the most common cause of viral lower respiratory tract infections (LRTI). Viral LRTI is a risk factor for bacterial superinfection, having an escalating incidence with increasing severity of respiratory illness. A study was undertaken to determine the incidence of pulmonary bacterial co-infection in infants and children with severe RSV bronchiolitis, using paediatric intensive care unit (PICU) admission as a surrogate marker of severity, and to study the impact of the co-infection on morbidity and mortality.

Methods: A prospective microbiological analysis was made of lower airways secretions on all RSV positive bronchiolitis patients on admission to the PICU during three consecutive RSV seasons.

Results: One hundred and sixty five children (median age 1.6 months, IQR 0.5-4.6) admitted to the PICU with RSV bronchiolitis were enrolled in the study. Seventy $(42.4 \%)$ had lower airway secretions positive for bacteria: 36 (21.8\%) were co-infected and 34 (20.6\%) had low bacterial growth/possible co-infection. All were mechanically ventilated (median 5.0 days, IQR 3.0-7.3). Those with bacterial co-infection required ventilatory support for longer than those with only RSV $(p<0.01)$. White cell count, neutrophil count, and C-reactive protein did not differentiate between the groups. Seventy four children $(45 \%)$ received antibiotics prior to intubation. Sex, co-morbidity, origin, prior antibiotics, time on preceding antibiotics, admission oxygen, and ventilation index were not predictive of positive bacterial cultures. There were 12 deaths (6.6\%), five of which were related to RSV.

Conclusions: Up to $40 \%$ of children with severe RSV bronchiolitis requiring admission to the PICU were infected with bacteria in their lower airways and were at increased risk for bacterial pneumonia.
$\mathrm{R}$ espiratory syncytial virus (RSV) is the most important viral cause for lower respiratory infection in infants and young children throughout the world. ${ }^{1}$ It is one of the commonest causes of respiratory tract infection leading to respiratory failure. It has been estimated that in each year 600000 deaths occur worldwide that are directly or indirectly attributable to RSV. ${ }^{1}$ Factors that increase susceptibility to the virus include chronological age less than 6 weeks, bronchopulmonary dysplasia, congenital heart disease, prematurity, and immunodeficiency. ${ }^{2-5}$ Although the mortality rate for those admitted to hospital may be as low as $1-3 \%$, it increases in those with severe bronchiolitis requiring intensive care management..$^{2-6}$ In developed countries about $2 \%$ of infants and children admitted to hospital with RSV require assisted ventilation. ${ }^{7}$ RSV bronchiolitis is a common cause for admission to a paediatric intensive care unit (PICU) in the winter season..$^{5-7}$

The pharmacological management of RSV bronchiolitis, other than the use of supplementary oxygen, has long been debated..$^{9}$ In particular, many advocate against the routine use of antibiotics in bronchiolitis because of a reported low incidence of concurrent or secondary bacterial infections in patients with RSV. ${ }^{10-17}$ However, these studies focused on extrapulmonary bacterial co-infection and included only limited numbers of children with severe respiratory compromise/failure.

Physiologically, the lower airways are normally sterile. Nevertheless, the relationship between bacterial co-infection and viral respiratory disease has previously been recognised, having an escalating incidence with increasing severity of respiratory illness. ${ }^{18}$ Three retrospective studies investigated the occurrence of bacterial co-infection in children with severe RSV infection requiring PICU admission and found the incidence of pulmonary bacterial co-infection to vary between $17.5 \%$ and $44 \%{ }^{19-21}$ In this study we prospectively investigated the incidence of pulmonary bacterial co-infection using established quantitative microbiology $y^{22}$ in patients with severe RSV bronchiolitis on admission to a tertiary PICU, and evaluated the impact of the bacterial co-infection on morbidity and mortality.

\section{METHODS}

The study group comprised children admitted to the PICU at the Royal Liverpool Children's Hospital, a university affiliated multidisciplinary regional referral centre. The PICU is a 20bed facility with an annual admission rate of over 1000 children. The overall mortality rate is $4.5 \%$, with a predicted mortality of $6.25 \%$ using the paediatric index of mortality ${ }^{23}$ and a standardised mortality rate of 0.72 .

The main objectives of the study were (1) to determine the incidence of pulmonary bacterial co-infection in patients requiring admission to the PICU for severe RSV bronchiolitis; and (2) to study the impact of the co-infection on morbidity (including length of ventilation and inflammation) and mortality.

Children with RSV bronchiolitis, confirmed by RSV antigen testing and/or culture, requiring PICU admission and from whom lower airway secretions were obtained on admission were included in the study. Those with nosocomial RSV infections were excluded. Data were collected prospectively

Abbreviations: BAL, bronchoalveolar lavage; LRTI, lower respiratory tract infection; PICU, paediatric intensive care unit; RSV, respiratory syncytial virus 
during three consecutive RSV seasons (winter) between 2002 and 2005 from RSV positive children admitted to the PICU.

The study was approved by the institutional ethics review board.

\section{Respiratory support}

Intubation was performed by our PICU retrieval team at the referring hospital, in our accident \& emergency (A\&E) department, or in one of the hospital wards prior to PICU admission. Alternatively, the anaesthetic team of the referring hospital intubated some of the patients before the arrival of the PICU retrieval team. It is policy that all children who require intensive care and ventilatory support are moved to the regional PICU.

The timing of extubation was judged clinically and not influenced by bronchoalveolar lavage (BAL) results.

\section{Microbiological sampling}

Diagnostic samples of nasopharyngeal aspirates (for RSV detection) and lower airway secretions (for bacterial culture) through endotracheal tube using sterile precautions ${ }^{24}$ were taken on admission and processed immediately in the laboratory. Prior to routine bronchial toilet, a sterile suction catheter was passed down the endotracheal tube. Two $1 \mathrm{ml} /$ $\mathrm{kg}$ aliquots of sterile $0.9 \%$ saline were instilled through the suction catheter, immediately followed by aspiration with constant pressure into a mucus trap. Samples were collected by specialist respiratory physiotherapists or PICU staff members. BAL was performed immediately after endotracheal intubation in children intubated in the hospital and on arrival in the PICU, and generally within 3 hours of endotracheal intubation for those admitted from other hospitals. All children within the region are only ventilated in the regional PICU, so are rapidly transferred to the PICU.

Surveillance samples of throat and rectum were obtained on admission and then twice weekly, in keeping with the routine surveillance practice in our unit.

\section{Laboratory procedures}

Viral

Nasopharyngeal aspirates were tested by the Directigen RSV test (Becton Dickinson Microbiology Systems, Maryland, USA). This is an in vitro enzyme immunoassay (ELISA) membrane test for the rapid and qualitative detection of RSV antigen directly from nasopharyngeal specimens. All samples negative for RSV using the ELISA membrane test were cultured using standard virological techniques at the Health Protection Agency.

\section{Bacterial/yeast}

Diagnostic or clinical samples were processed immediately in a qualitative and semi-quantitative way using standard microbiological methods. For all types of samples, macroscopically distinct colonies were isolated in pure culture. Standard methods for identification, typing, and sensitivity patterns were used for all micro-organisms. ${ }^{25}$

\section{Antibiotic treatment}

Patients with signs of infection received intravenous cefotaxime ( $150 \mathrm{mg} / \mathrm{kg} /$ day four times daily for up to 7 days) as first line treatment for 48 hours while awaiting culture results. Clinical status on presentation governed whether supplementary intravenous cover with an aminoglycoside (gentamicin $7.5 \mathrm{mg} / \mathrm{kg} /$ day three times daily for up to 7 days) was added. Antibiotics were rationalised once culture and sensitivity results became available.

\section{Definitions}

Bacteria positive: the presence of micro-organisms in the lower airways which is normally sterile.

Co-infection: Infection is a microbiologically proven, clinical diagnosis of inflammation, local and/or generalised. In this study clinical signs were unreliable as all patients had bronchiolitis, so microbiological definitions were used. Bacterial co-infection required bacteria colony counts $\geqslant 10^{5} \mathrm{cfu} / \mathrm{ml}$ of diagnostic sample for each single species obtained from lower airway secretions and, on a semiquantitative scale of $+=$ few $\left(<50 \times 10^{6} / 1\right),++=$ moderate $\left(>100 \times 10^{6} / 1\right)$, and $+++=$ many leucocytes $\left(>1000 \times 10^{6} / 1\right)$, the presence of at least a moderate $(++)$ number of leucocytes. ${ }^{26-28}$

Low bacterial growth: Diagnostic samples from lower airway secretions which yielded $<10^{5} \mathrm{cfu} / \mathrm{ml}$ of diagnostic sample and the presence leucocytes.

The chest radiographic appearance was not used to diagnose bacterial co-infection as changes on the chest radiograph are not pathognomonic of secondary bacterial or viral infections..$^{18} 29$

\section{Analysis of data}

Data were collected prospectively. Prediction of mortality using the paediatric index of mortality was obtained on the patient's first contact with the PICU team. ${ }^{23}$ Results were expressed as a percentage of the total study population; median and interquartile ranges (IQR) were used to describe the demographic distributions.

Continuous data were analysed using the Wilcoxon-MannWhitney (W-M-W) test. Categorical data were analysed using Fisher's exact or McNemar's test. Correlation was assessed using Spearman's rank test (two tailed). Multivariate analysis was performed using linear and logistic regression analysis.

Statistical calculations were performed with the Statistical Program for Social Science release 11.0.0 (SPSS 11, Chicago, IL, USA). A p value of $<0.05$ was considered statistically significant.

\section{RESULTS}

A total of 181 children ( 103 boys and 78 girls) of median age 1.6 months (IQR 0.5-4.6) were admitted to the PICU with RSV positive bronchiolitis during the three consecutive RSV seasons (2002-5). The indication for PICU admission for these children was ventilatory/respiratory support (respiratory failure $(\mathrm{n}=172)$ and/or life threatening apnoeas $(n=9))$. All patients were mechanically ventilated for a median of 5.0 days (IQR 3.0-7.3). 165 children were enrolled in the study; an admission BAL sample was not available in 16 patients $(8.8 \%)$.

The demographic characteristics, inflammatory markers, antibiotic history, and mortality of the RSV positive children in the subgroups RSV only, bacterial co-infection, low bacterial growth, and bacteria positive (co-infection + low bacterial growth) are shown in table 1 . The white cell count, neutrophil count, and C-reactive protein (CRP) levels did not differ between the groups on admission or during days $1-5$ in the PICU.

Although all patients were admitted primarily for respiratory disease, $43 \%(71 / 165)$ of them had other co-morbidities ( congenital heart disease $n=37$, chronic lung disease $n=8$, immunodeficiencies $\mathrm{n}=4$, abnormality of large airways $\mathrm{n}=5$, congenital heart disease and abnormality of large airways $\mathrm{n}=8$, congenital heart disease and chronic lung disease $n=4$, neuromuscular disease $n=7$ ). Co-morbidity did not increase the risk of positive bacterial cultures (odds ratio $0.77,95 \%$ CI 0.55 to 1.09 ). 
Table 1 Patient characteristics according to culture result $(n=165)$

\begin{tabular}{|c|c|c|c|c|}
\hline & RSV only & $\begin{array}{l}\text { Bacterial co-infection } \\
\left(>10^{5} \mathrm{cfu} / \mathrm{ml}\right)\end{array}$ & $\begin{array}{l}\text { Low bacterial growth } \\
\left(<10^{5} \mathrm{cfu} / \mathrm{ml}\right)\end{array}$ & $\begin{array}{l}\text { Bacteria positive (co- } \\
\text { infection + low bacterial } \\
\text { growth) }\end{array}$ \\
\hline$N(\%$ of total) & $95(57.6 \%)$ & $36(21.8 \%)$ & $34(20.6 \%)$ & $70(42.4 \%)$ \\
\hline Origin (retrieved/intra-hospital/A\&E) & $48 / 29 / 18$ & $11 / 17 / 8$ & $14 / 11 / 9$ & $25 / 28 / 17$ \\
\hline Age (months) & $1.4(0.4-3.9)$ & $\begin{array}{l}1.3(0.7-2.5) \\
p=0.8^{*}\end{array}$ & $\begin{array}{l}3.5(1.2-10) \\
p=0.04 \dagger\end{array}$ & $\begin{array}{l}1.8(0.9-4.6) \\
p=0.9 \ddagger\end{array}$ \\
\hline Paediatric index of mortality & $0.08(0.03-0.12)$ & $\begin{array}{l}0.09(0.04-0.14) \\
p=0.6^{*}\end{array}$ & $\begin{array}{l}0.08(0.06-0.12) \\
p=0.5^{\dagger}\end{array}$ & $\begin{array}{l}0.08(0.05-0.13) \\
p=0.6 \ddagger\end{array}$ \\
\hline Length of ventilation (days) & $4(3-7)$ & $\begin{array}{l}6(4-8) \\
p<0.01^{*}\end{array}$ & $\begin{array}{l}6(5-9) \\
p<0.01 \dagger\end{array}$ & $\begin{array}{l}6(4-8) \\
p<0.01 \ddagger\end{array}$ \\
\hline Admission OI in PICU & $8(5-12)$ & $\begin{array}{l}6(4-9) \\
p=0.2^{*}\end{array}$ & $\begin{array}{l}9(6-12) \\
p=0.6 \dagger\end{array}$ & $\begin{array}{l}7(4-11) \\
p=0.7 \ddagger\end{array}$ \\
\hline Admission $\mathrm{VI}$ in $\mathrm{PICU}$ & $26(18-39)$ & $\begin{array}{l}27(16-44) \\
p=0.9^{*}\end{array}$ & $\begin{array}{l}26(20-32) \\
p=0.2 \dagger\end{array}$ & $\begin{array}{l}27(19-39) \\
p=0.8 \ddagger\end{array}$ \\
\hline $\begin{array}{l}\text { White cell count }\left(\times 10^{9} \text { cells } / \text { I) on PICU }\right. \\
\text { admission }\end{array}$ & $9.8(7.2-13.7)$ & $\begin{array}{l}10.6(7.1-13.5) \\
p=0.5^{*}\end{array}$ & $\begin{array}{l}11.5(6.9-14.7) \\
p=0.6 \dagger\end{array}$ & $\begin{array}{l}11.3(7.1-13.8) \\
p=0.4 \ddagger\end{array}$ \\
\hline $\begin{array}{l}\text { Neutrophil count }\left(\times 10^{9} \text { cells } / I\right) \text { on PICU } \\
\text { admission }\end{array}$ & $5.2(2.9-7.6)$ & $\begin{array}{l}7.1(3.9-10.3) \\
p=0.1^{*}\end{array}$ & $\begin{array}{l}5.8(3-10.3) \\
p=0.9 \dagger\end{array}$ & $\begin{array}{l}6.2(3.6-10.3) \\
p=0.2 \ddagger\end{array}$ \\
\hline CRP (mg/l) on PICU admission & $14(4-45)$ & $\begin{array}{l}14(5-52) \\
p=0.9^{*}\end{array}$ & $\begin{array}{l}21(4-46) \\
p=0.9 \dagger\end{array}$ & $\begin{array}{l}18(4-49) \\
p=0.9 \ddagger\end{array}$ \\
\hline Antibiotics before PICU admission & $48 \%$ & $36 \%$ & $44 \%$ & $\begin{array}{l}40 \% \\
p=0.08 \ddagger\end{array}$ \\
\hline Time on prior antibiotics (days) & $1(1-2)$ & $1(1-3)$ & $1(1-3)$ & $1(1-3)$ \\
\hline Mortality (RSV related deaths) & $8(3)$ & $2(1)$ & $2(1)$ & $4(2)$ \\
\hline Percentage with co-morbidities§ & $40 \%$ & $61 \%$ & $41 \%$ & $\begin{array}{l}51 \% \\
p=0.6 \ddagger\end{array}$ \\
\hline \multicolumn{5}{|c|}{$\begin{array}{l}\text { Data shown as median (IQR). } \\
\text { cfu/ml, colony forming units of a single bacterial species per } \mathrm{ml} \text { of diagnostic sample; } \mathrm{Ol} \text {, oxygen index (mean airways pressure }(\mathrm{MAP}) \times \mathrm{FiO} 2 / \mathrm{PaO} 2) ; \mathrm{VI} \text {, } \\
\text { ventilation index (respiratory rate } \times \mathrm{PaCO}_{2} \times \text { peak inspiratory pressure/1000); CRP, C-reactive protein; PICU, paediatric intensive care unit. } \\
\text { *RSV only } v \text { bacterial co-infection. } \\
\text { †RSV only } v \text { low bacteria growth. } \\
\text { tRSV only } v \text { all those positive for bacteria (bacterial co-infection }+ \text { low bacteria growth). } \\
\text {-Retrieved, patients retrieved from other hospitals; intra-hospital, patients admitted from wards within our hospital; A\&E, patients admitted directly from the } \\
\text { Accident \& Emergency department. } \\
\text { §Co-morbidities = congenital heart disease, chronic lung disease, abnormality of large airways, immunodeficiencies, neuromuscular disease. } \\
\text { Wilcoxon-Mann-Whitney test used for comparisons except for prior antibiotics and co-morbidities (McNemar's test). }\end{array}$} \\
\hline
\end{tabular}

Overall, 45\% (74/165) received antibiotics before admission to the PICU (that is, started by the referring hospital or ward), most often cefotaxime or ceftriaxone. The breakdown between the subgroups is shown in table 1. Receipt of antibiotics before PICU admission did not affect the paediatric index of mortality $(\mathrm{p}=0.6, \mathrm{~W}-\mathrm{M}-\mathrm{W}$ test $)$ and length of ventilation $(\mathrm{p}=0.2, \mathrm{~W}-\mathrm{M}-\mathrm{W}$ test). All except eight

Table 2 Bacterial isolates $(n=98)$ obtained on admission to the PICU from the lower airway in 70 children with severe RSV bronchiolitis

\begin{tabular}{|c|c|c|}
\hline & $\begin{array}{l}\text { Co-infection } \\
\left.\text { (>10 } 10^{5} \mathrm{cfu} / \mathrm{ml}\right)\end{array}$ & $\begin{array}{l}\text { Low bacterial } \\
\text { growth } \\
\text { (<10 }\end{array}$ \\
\hline \multicolumn{3}{|l|}{ Community organisms $^{28} 30$} \\
\hline$H$ influenzae & 17 & 11 \\
\hline$S$ aureus & 10 & 12 \\
\hline$M$ catarrhalis & 8 & 10 \\
\hline S pneumoniae & 6 & 6 \\
\hline$S$ pyogenes & 1 & \\
\hline \multicolumn{3}{|l|}{ Abnormal organisms ${ }^{28} 30_{*}$} \\
\hline$P$ aeruginosa & 4 & 3 \\
\hline B pertussis & 1 & \\
\hline K pneumoniae & 1 & 1 \\
\hline E coli & 1 & 1 \\
\hline E cloacae and $C$ freundii & 1 & \\
\hline$P$ mirabilis & & 1 \\
\hline S agalactiae & & 1 \\
\hline$N$ meningitidis & & 1 \\
\hline MRSA & & 1 \\
\hline
\end{tabular}

23 patients had multiple organisms (18 had two, 5 had three bacteria) community organisms were involved in $91 \%$ of these cases compared with $77 \%$ single isolates ( $p=0.2$, Fisher's exact test).

*67\% (10/15) had chronic illnesses. patients were continued or commenced on antibiotics in the PICU (usually cefotaxime). Antibiotics were continued for a median of 5 days (IQR 3-6). The empirical use of antibiotics was at the discretion of the attending consultant.

Sex, age, paediatric index of mortality, co-morbidity, receipt of prior antibiotics, time on antibiotics before intubation, admission oxygen and ventilation index were not predictive of positive bacterial cultures by univariate or multivariate analysis (all p values $>0.16$ )

The organisms isolated from lower airway secretions obtained on admission are shown in table 2. All those with positive endotracheal bacteriological specimens had the same organisms isolated on admission surveillance swabs. Community organisms accounted for $83 \%$ (81/98) of the bacteria cultured.

There were 12 deaths (6.6\%), five of which (2.8\%) appeared to be RSV related as the patients were still RSV positive when they died. Two patients with leukaemia on chemotherapy died from RSV pneumonitis on days 1 and 16, respectively. Neither had proven bacterial co-infection and both received broad spectrum empirical antibiotic treatment. Other associated causes included singles cases of hypoplastic right heart coupled with cystic fibrosis (on day 8), B pertussis co-infection with hypoxaemic respiratory failure requiring extracorporeal membrane oxygenation (on day 26), and a child with a congenital myopathy (on day 8). The remaining seven deaths occurred 6-31 days after admission subsequent to the RSV cultures becoming negative. Causes of these RSV "unrelated" deaths included complex congenital heart disease $(n=3)$, multiple congenital anomalies $(n=2)$, congenital myopathy $(\mathrm{n}=1)$, anoxic brain injury $(\mathrm{n}=1)$. Positive bacterial cultures did not predict death (odds ratio $1.3,95 \%$ CI 0.57 to 2.95 ), but co-morbidity did (odds ratio $0.51,95 \%$ CI 0.37 to 0.7$)$. 


\section{DISCUSSION}

This observational study over three consecutive RSV seasons evaluating bacterial pulmonary co-infection found that $42 \%$ of children admitted with severe RSV infection harboured bacterial pathogens in their lower airways. These critically ill children run a serious risk of developing bacterial pneumonia. ${ }^{18} 31$

BAL samples were collected very soon after intubation so significant growth densities of bacteria reflect pathogens in the normally sterile lower airways. The high number of colony forming units makes it highly unlikely that the microorganisms isolated were "pushed down" the trachea on intubation. We acknowledge that the number of leucocytes in lower airways secretions will also be influenced by RSV infection and therefore relied on bacterial growth. The microbiological criteria were strict and avoided potentially confounding clinical factors. This microbiological approach is supported by recent literature concerning ventilator associated pneumonia (VAP). ${ }^{32}$ On the other hand, it must be appreciated that our study group was very different from this VAP group as they had "virgin" iatrogenically uncontaminated lower airways. Certainly, in the group with coinfection, substantial bacterial growth densities occurred far too soon after intubation to have been oropharyngeal flora transported there by the endotracheal tube. If anything, the strict microbiological criteria probably underestimated the number co-infected by categorising many of them as having low bacterial growth. We accept that differentiating the groups into "co-infected" and "low bacterial growth" may be somewhat artificial as the lower respiratory tract should be free from bacteria.

The term "co-infection" was used as, at the time of PICU admission, these infections could either be secondary or concurrent. It would not be easy to detect the "chicken" from the "egg" as far as which was primary-the RSV or the bacteria-although a viral infection destroying cilia is in general required for a bacterial co-infection. ${ }^{18}$ The true coinfection rate is likely to be higher than the $22 \%$ rate detected, as $45 \%$ of the cases received antibiotics before admission to the PICU. These antibiotics may have converted some of the "co-infection" patients into the "low bacterial growth" group, or even prevented bacterial growth altogether.

Previous studies have examined bloodstream, otitis media, or urinary tract infections in children with bronchiolitis, very few of whom had severe RSV bronchiolitis requiring intensive care. ${ }^{10-17}$ These studies generally found a very low incidence of secondary serious bacterial infection $(1.2 \%)^{14}$ or bacteraemia $(0.6 \%)^{16}$ in their hospitalised RSV patients. Because these studies did not specifically concentrate on those with severe bronchiolitis, it is difficult to extrapolate their results to this population. Duttweiler et al retrospectively studied 127 infants admitted to intensive care for RSV bronchiolitis and found that 25 (44\%) of the 57 ventilated and endotracheally sampled infants had "concomitant bacteria pneumonia". ${ }^{19}$ Similarly, the retrospective study of Kneyber et $a l^{20}$ (82 PICU admissions with 65 (79\%) ventilated) found that nine (33\%) of the 24 children on whom admission endotracheal aspirates were performed had a positive bacterial culture. Randolph et $a^{21}$ retrospectively examined 165 previously healthy infants admitted to the intensive care unit over a 12 year period with laboratory confirmed RSV infection, 63 (38\%) of whom required mechanical ventilation. They found that $17.5-38 \%$ of the 63 intubated infants had "probable" or "possible" bacterial pneumonia. The incidence of bacterial pulmonary infection in these retrospective PICU reports is in keeping with that of this prospective study in which all bronchiolitic admissions were included.
Fifty one percent of the patients with bacteria in their airways and $40 \%$ of the children with RSV only had comorbidities (congenital heart disease, chronic lung disease, large airway abnormality, immunodeficiency, neuromuscular disease). This is in keeping with well recognised risk factors associated with more severe RSV disease. ${ }^{3461634}$ Co-morbidities did not account for differences in length of ventilation between the study groups, but did contribute towards mortality. The high percentage with co-morbidities is most probably also influenced by the fact that our centre is the regional paediatric cardiac referral centre, which means that children with congenital heart disease and bronchiolitis are more likely to be referred to our PICU for intensive care management.

There were fewer deaths in the bacteria positive group than in those with RSV only. However, when adjusted for those children who had recovered from their RSV infection only to die later from RSV unrelated causes, both groups had similar mortalities $(2.9 \% v 3.2 \%)$. The paediatric index of mortality is a point of first contact score that is used to assess the risk of death while in the PICU. ${ }^{23}$ The paediatric index of mortality scores for all the groups were similar, suggesting that all groups had matching severity of illness on admission to the PICU. Yet those with positive bacterial cultures required ventilatory support for longer than those with RSV only. Kneyber $e t a^{20}$ reported a similar finding. Although length of ventilation was significantly different between the groups, other respiratory support and inflammation indices did not differ between them (table 1). Perhaps the general inflammatory response once triggered by RSV is not so refined as to be further enhanced by concomitant bacterial infection. Others have also found inflammatory markers unhelpful in differentiating bacterial infection in this group of patients. $^{203536}$ Unfortunately, we were unable to find any early clinical measurements which would identify which RSV patients had bacterial co-infection.

Receipt of prior antibiotics and length of time on them did not predispose to bacterial co-infection. Moreover, many of the children with RSV had received antibiotics for only one day or less (often a single dose close to intubation). The fact that nearly all the RSV positive children received antibiotics in our PICU limited any interpretation on the impact of antibiotics on their outcome. All those patients with positive bacteriology in their endotracheal secretions had the same organisms isolated on admission surveillance swabs, indicating primary endogenous infection. ${ }^{37}$ This reinforces the view that potential pathogens are carried first in the nasopharynx and then there is migration down the trachea into the lower airways. $^{37} 38$ The organisms isolated on admission were generally normal community organisms because most of the patients were in good health before RSV infection and PICU admission. ${ }^{27} 29$ Pseudomonas aeruginosa was the most common of the abnormal bacteria (table 2). All these patients were carriers of abnormal organisms in their throats, and in most the common denominator for their abnormal carriage was chronic illness. ${ }^{37}{ }^{39}$ Interestingly, Streptococcus pneumoniae was isolated from relatively few patients. This could be the result of prior antibiotic use..$^{40}$

Although most LRTI in children are viral in aetiology, mixed viral/bacterial infections are seen in up to a quarter of hospitalised children. ${ }^{41}{ }^{42}$ In addition, there is a risk of developing bacterial superinfection with viral LTRI. ${ }^{18}$ These issues have contributed to the recommendations by the World Health Organization that the treatment of community acquired pneumonia should include empirical antibiotics. ${ }^{41}{ }^{43}$ Concerns that using antibiotics (in our case cefotaxime) preemptively in this group of critically ill children would breed antibiotic resistance have been shown to be unfounded in a 4 year study. ${ }^{44}$ Assessment of the influence of antibiotics on 
children with severe bronchiolitis would require a prospective randomised controlled trial.

This study has shown that up to $40 \%$ of patients admitted with severe RSV bronchiolitis were infected with bacteria in their lower airways. Co-morbidity (congenital heart disease, chronic lung disease, large airway abnormality, immunodeficiency, neuromuscular disease) predisposes to more severe RSV disease.

\section{Authors' affiliations}

K Thorburn, S Harigopal, V Reddy, Department of Paediatric Intensive Care, Royal Liverpool Children's Hospital, Liverpool, UK

K Thorburn, N Taylor, H K F van Saene, Department of Medical Microbiology, The University of Liverpool, Liverpool, UK

Funding: none.

The authors have no financial or ethical conflicts of interest or any other competing interests with regard to the contents of this manuscript.

\section{REFERENCES}

1 Howard TS, Hoffman LH, Stang PE, et al. Respiratory syncytial virus pneumonia in the hospital setting: length of stay, charges, and mortality. J Pediatr 2000;137:227-32.

2 Navas L, Wang E, de Carvalho V, et al. Improved outcome of respiratory syncytial virus infection in a high-risk hospitalised population of Canadian children. Pediatric Investigators Collaborative Network on Infections in Canada. J Pediatr 1992;121:348-54.

3 MacDonald NE, Hall CB, Suffin SC, et al. Respiratory syncytial viral infection in infants with congenital heart disease. N Engl J Med 1982;307:397-400.

4 Langley JM, Le Blanc JC, Wang EE, et al. Nosocomial respiratory syncytial virus infection in Canadian pediatric hospitals: a Pediatric Investigators Collaborative Network on Infections in Canada Study. Pediatrics 1997; 100:943-6.

5 Buckingham SC, Quasney MW, Bush AJ, et al. Respiratory syncytial virus infections in the pediatric intensive care unit: clinical characteristics and risk factors for adverse outcomes. Pediatr Crit Care Med 2001;2:318-23.

6 Thorburn K, Kerr S, Taylor N, et al. Respiratory syncytial virus outbreak in a paediatric intensive care unit. J Hosp Infect 2004;57:194-201.

7 Behrendt CE, Decker MD, Burch DJ, et al. International variation in the management of infants hospitalised with respiratory syncytial virus. International RSV Study Group. Eur J Pediatr 1998;157:215-20.

8 Harrison AM, Boeing NM, Domachowske JB, et al. Effect of RSV bronchiolitis practice guidelines on resource utilization. Clin Pediatr (Phila) 2001;40:489-95.

9 Simoes EA. Respiratory syncytial virus infection. Lancet 1999;354:847-52.

10 Purcell K, Fergie J. Concurrent serious bacterial infections in 2396 infants and children hospitalised with respiratory syncytial virus lower respiratory tract infections. Arch Pediatr Adolesc Med 2002;156:322-4

11 Friis B, Andersen P, Brenoe E, et al. Antibiotic treatment of pneumonia and bronchiolitis. A prospective randomised study. Arch Dis Child 1984;59:1038-45.

12 Todd JK. Antibiotics for respiratory syncytial virus infection. Pediatr Infect Dis J 1990;9:754.

13 Titus MO, Wright SW. Prevalence of serious bacterial infections in febrile infants with respiratory syncytial virus infection. Pediatrics 2003;112:282-4.

14 Hall CB, Powell KR, Schnabel KC, et al. Risk of secondary bacterial infection in infants hospitalised with respiratory syncytial viral infection. J Pediatr 1988;113:266-71.

15 Kuppermann N, Bank DE, Walton EA, et al. Risks for bacteremia and urinary tract infections in young febrile children with bronchiolitis. Arch Pediatr Adolesc Med 1997;151:1207-14.

16 Bloomfield P, Dalton, Karleka A, et al. Bacteraemia and antibiotic use in respiratory syncytial virus infections. Arch Dis Child 2004;39:363-7.

17 Korppi M, Leinonen $M$, Koskela $M$, et al. Bacterial co-infection in children hospitalized with respiratory syncytial infections. Pediatr Infect Dis $J$ 1989:8:687-92.

18 Hament JM, Kimpen JL, Fleer A, et al. Respiratory viral infection predisposing for bacterial disease: a concise review. FEMS Immunol Med Microbiol 1999;26:189-95
19 Duttweiler L, Nadal D, Frey B. Pulmonary and systemic bacterial co-infections in severe RSV bronchiolitis. Arch Dis Child 2004;89:1155-7.

20 Kneyber MCJ, Blusse van Oud-Albas H, van Vliet $M$, et al. Concurrent bacterial infection and prolonged mechanical ventilation in infants with respiratory syncytial virus lower respiratory tract infection. Intensive Care Med 2005; 131:680-5.

21 Randolph AG, Reder L, Englund JA. Risk of bacterial infection in previously healthy respiratory syncytial virus-infected young children admitted to the intensive care unit. Pediatr Infect Dis J 2004;23:990-4.

22 American Thoracic Society. Infectious Diseases Society of America. Guidelines for the management of adults with hospital-acquired, ventilatorassociated, and healthcare-associated pneumonia. Am J Respir Crit Care Med 2005; 171:388-416.

23 Shann F, Pearson G, Slater A, et al. Paediatric index of mortality (PIM): a mortality prediction model for children in intensive care. Intensive Care Med 1997;23:201-7.

24 de Blic J, Midulla F, Barbato A, et al. Bronchoalveolar lavage in children. ERS Task Force on bronchoalveolar lavage in children. European Respiratory Society. Eur Respir J 2000;15:217-31.

25 Brook I. Bacterial colonization, tracheobronchitis, and pneumonia following tracheostomy and longterm intubation in paediatric patients. Chest 1979;78:420-4.

26 Sarginson RE, Taylor N, Van Saene HKF. Glossary of terms and definitions. Curr Anaesth Crit Care $2001 ; 12: 2-5$.

$27 \mathrm{~A}^{\prime}$ Court CH, Garrard CS, Crook D, et al. Microbiological lung surveillance in mechanically ventilated patients, using non-directed bronchial lavage and quantitative culture. Q J Med 1993;86:635-48.

28 van Saene HKF, Damjanovic V, Alcock SR. Basics in microbiology for the patient requiring intensive care. Curr Anaesth Crit Care 2001;12:6-7.

29 Friis $B$, Hornsleth A, Jensen A. Chest X-ray appearances in pneumonia and bronchiolitis. Correlation to virological diagnosis and secretory bacterial findings. Acta Pediatr Scand 1990;2:318-25.

30 Mobbs KJ, van Saene HK, Sunderland D, et al. Oropharyngeal Gramnegative bacillary carriage: a survey of 120 healthy individuals. Chest 1999;115:1570-5.

31 Liberati A, D'Amico R, Pifferi, Torri V, et al. Antibiotic prophylaxis to reduce respiratory tract infections and mortality in adults receiving intensive care (Cochrane Review). The Cochrane Library, Issue 1. Chichester, UK: John Wiley \& Sons Ltd, 2004.

32 Gauvin F, Dassa C, Chaibou M, et al. Ventilator-associated pneumonia in intubated children: comparison of different diagnostic methods. Pediatr Crit Care Med 2003:4:437-43.

33 Gauvin F, Lacroix J, Guertin MC, et al. Reproducibility of blind protected bronchoalveolar lavage in mechanically ventilated children. Am J Respir Crit Care Med 2002; 165:1618-23.

34 Hall CB. Medical progress: respiratory syncytial virus and parainfluenza virus. N Engl J Med 2001;344:1917-28.

35 Toikka P, Irjala K, Juven T, et al. Serum procalcitonin, C-reactive protein and interleukin- 6 for distinguishing bacterial and viral pneumonia in children Pediatr Infect Dis J 2000; 19:598-602.

36 Resch B, Gusenleitner W, Müller W. Procalcitonin, interleukin-6, C-reactive protein and leukocyte counts in infants with bronchiolitis. Pediatr Infect Dis $J$ 2003;22:475-6.

37 van Saene HKF, Stoutenbeek CP, Torres A. The abnormal oropharyngeal carrier state: symptom or disease? Respir Med 1992:86:183-6.

38 van Uffelen R, van Saene HK, Lowenberg A. Oropharyngeal flora as a source of bacteria colonizing the lower airways in patients on artificial ventilation. Intensive Care Med 1984; 10:233-7.

39 Gilman R, Brown K, Gilman J, et al. Colonisation of the oropharynx with gram-negative bacilli in children with severe protein calorie malnutrition. Am J Clin Nutr 1982;36:284-9.

40 Sirvent JM, Torres A, El-Ebiary M, et al. Protective effect of intravenously administered cefuroxime against nosocomial pneumonia in patients with structural coma. Am J Respir Crit Care Med 1997:155:1729-34.

41 Korppi M. Community-acquired pneumonia in children: issues in optimizing antibacterial treatment. Paediatr Drugs 2003;5:821-32.

42 Michelow IC, Olsen K, Lozano J, et al. Epidemiology and clinical characteristics of community-acquired pneumonia in hospitalized children. Pediatrics 2004;113:701-7.

43 World Health Organization. Essential drugs and medicines policy. Drugs used in bacterial infections. Available at http://www. who.int/medicines/ library/bacterial_model_pres/bacterial_content.shtml (accessed 4 November 2005).

44 Sarginson RE, Taylor N, Reilly N, et al. Infection in prolonged pediatric critical illness: a prospective four-year study based on knowledge of the carrier state. Crit Care Med 2004;32:839-47 